\title{
THE CANADIAN FOUNDATION FOR DISPUTE RESOLUTION
}

\author{
W.J. HARTNETT ${ }^{*}$
}

\section{MISSION AND OBJECTIVES}

The Canadian Foundation for Dispute Resolution is a nonprofit alliance of business corporations and law firms in Canada working together to promote the creative resolution of business disputes. Objectives include:

(1) promoting awareness of the full range of alternative dispute resolution techniques for commercial disputes;

(2) encouraging corporations and law firms to take a leadership role in demonstrating the value of alternative dispute resolution and integrating it into the mainstream of business practices;

(3) promoting the adoption of a corporate policy statement which commits signatory corporations to willingly consider alternative dispute resolution processes in appropriate cases prior to beginning litigation; and

(4) promoting the adoption of a law firm policy statement to encourage signatory law firms to demonstrate a commitment to alternative dispute resolution capability in advising clients and assisting them in reaching cost-effective resolution of business disputes.

\section{SERVICES}

The Canadian Foundation for Dispute Resolution provides a variety of services which include:

(1) a distinguished roster of "neutrals" with appropriate experience, capability and specialization, from which parties may make a fully-informed choice;

(2) training and a clearinghouse for resource material for those at the frontlines of disputes - business clients, inhouse lawyers and their private practice lawyers - through conferences, inhouse seminars, training materials, model procedures and model clauses;

(3) dispute-audit consulting to assess the suitability of various alternative dispute resolution techniques to a particular dispute; 
(4) dispute-resolution "emissary" facilitation to demonstrate - in the context of a particular dispute - the value of appropriate alternative dispute resolution options to parties who may be unfamiliar with the potential benefits;

(5) independent "early-neutral evaluation" to enable corporations to assess the merits of a particular dispute and alternative cost scenarios; and

(6) administrative services - such as helping to formulate case-specific agreements on ground rules or procedures, arranging for meeting facilities and ensuring the overall integrity of the dispute-resolution process.

\section{THE DISPUTE-RESOLUTION PROTOCOL}

A Canadian Foundation for Dispute Resolution initiative is to encourage corporations and law firms across Canada to sign its "dispute-resolution protocol" which commits signatories to willingly consider and suggest alternative dispute resolution processes in appropriate situations prior to turning to the courts.

The protocol is similar in concept to a policy statement on alternatives to litigation developed by the CPR Institute for Dispute Resolution in New York several years ago. The corporate policy statement - otherwise known as the "pledge" - has been signed by over 850 corporations and 2,800 corporate subsidiaries. A corresponding law firm policy statement has been signed by over 1,500 law firms.

The primary value to a corporation in signing the dispute-resolution protocol is that it enables the corporation to suggest alternatives to litigation in a particular dispute without causing the other party to believe that the suggestion arises because of a perception of weakness in its case. This is because the signature of the company's chief executive officer and general counsel (if the company has one) shows that the commitment is company policy and that suggestions to consider alternative dispute resolution will be made in all appropriate situations. And the fact that the protocol has the force of a corporate policy statement also encourages greater acceptance of alternative dispute resolution within the corporation itself.

The corresponding protocol for law firms involves making a commitment to promote awareness and skills development in alternative dispute resolution and acknowledging that they have an important role to play in effectively resolving business disputes at potentially lower costs to their clients.

\section{DISTINCTIVENESS OF THE FOUNDATION}

The Canadian Foundation for Dispute Resolution differs from most other organizations focusing on alternative dispute resolution. It does not provide professional mediation or arbitration services; rather it assists those needing such services to find appropriately qualified neutrals. The Foundation's mission, objectives and services have a particularly distinctive "user-focus." 
The Foundation began as an initiative of corporate general counsels through the Association of General Counsel of Alberta and a steering committee consisting of representatives of that organization and major Calgary law firms. The steering committee made a feasibility assessment and decided to incorporate the Foundation in August 1994.

Founding members include: Alberta Energy Company; Alberta Wheat Pool; Canadian Airlines International; Chevron; Direct Energy; Fluor Daniel; Home Oil; Imperial Oil; Mobil; Norcen; Petro-Canada; Poco Petroleum; ProGas; Shell Canada; Suncor; Syncrude Canada; Transwest Energy; Trimac; Western Gas Marketing; Ballem McDill MacInnes Eden; Bennett Jones Verchere; Burnet, Duckworth \& Palmer; Code Hunter Wittmann; Howard Mackie; Macleod Dixon; McCarthy Tetrault and Milner Fenerty.

\section{HOW TO CONTACT THE FOUNDATION}

The executive director is S.N. (Noel) Rea and his assistant is Lori Bazin. There are offices in Calgary and Toronto:

The Canadian Foundation for Dispute Resolution 12089 - 237 4th Avenue S.W.

Calgary, Alberta

T2P $0 \mathrm{H} 6$

Telephone: (403) 237-2872

Facsimile: (403) 237-2753

The Canadian Foundation for Dispute Resolution

112 Adelaide Street East

Toronto, Ontario

M5C $1 \mathrm{~K} 9$

Telephone: (403) 307-0019

Facsimile: (403) 307-0011 